\title{
PENGENALAN TENTANG MASAKAN SUNDA DI KALANGAN REMAJA KECAMATAN KIARACONDONG
}

\author{
Jasmine Cahya Putri ${ }^{1}$, Elly Lasmanawati ${ }^{1}$, Tati Setiawati $^{1}$ \\ Program Studi Pendidikan Tata Boga, Departemen Pendidikan Kesejahteraan \\ Keluarga, Fakultas Teknologi dan Kejuruan, Universitas Pendidikan Indonesia \\ jasminecahya@gmail.com
}

\begin{abstract}
Abstrak: Perkembangan kuliner khas Sunda yang beraneka ragam mulai dari makanan pokok, selingan, hingga makanan sepinggan, namun generasi muda sudah tidak mau lagi untuk makan masakan khas sunda, mereka lebih memilih untuk makan masakan modifikasi, makanan Fast Food, makanan western, dan lain-lain yang menjadi salah satu faktor kurangnya pengetahuan remaja akan masakan sunda. Tujuan umum dalam penelitian ini adalah untuk memperoleh informasi atau gambaran mengenai pengetahuan remaja suku sunda mengenai pengenalan nama dan ciri - ciri masakan khas sunda populer yang termasuk di dalamnya makanan pokok, lauk pauk hewani, lauk pauk nabati, sayuran, dan penyerta. Metode yang digunakan pada penelitian ini yaitu kuantitatif dengan instrument berupa angket dan test. Hasil penelitian ini menunjukkan bahwa sebagian besar responden memiliki pengetahuan mengenai mengenal nama dan ciri - ciri masakan sunda populer yang terdiri dari makanan pokok, lauk pauk hewani, lauk pauk nabati, sayuran, dan penyerta. Perbedaan yang terlihat antara hasil angket dan tes terdapat pada hidangan Nasi Tutug Oncom, Ayam Serundeng, Sate Maranggi, Pepes Tahu, Oseng Oncom, Ulukutek Leunca, Karedok, dan Sambal Tauco. Berdasarkan hasil penelitian ini diharapkan para orang tua dan tenaga pendidik yang terkait dapat lebih meningkatkan kesadaran akan pentingnya mengajarkan masakan khas sunda terutama hidangan memiliki perbedaan antara hasil angket dan tes kepada siswa agar dapat terjaga kelestariannya, sehingga dapat diwariskan ke generasi selanjutnya.
\end{abstract}

Kata kunci : Pengetahuan Remaja, Kuliner, Masakan Sunda

\section{PENDAHULUAN}

Perkembangan kuliner khas Sunda yang beraneka ragam mulai dari makanan pokok, selingan, hingga makanan sepinggan menjadi salah satu aset kebudayaan yang dimiliki oleh masyarakat suku Sunda yang patut untuk dilestarikan. Salah satu cara untuk melestarikan kuliner khas sunda adalah dengan mewariskannya secara turun temurun kepada generasi selanjutnya. Namun pada Era digital seperti ini, sudah banyak ditinggalkan hal-hal yang berbau tradisional, segala sesuatu bersifat mudah dan cepat. Generasi muda sudah tidak mau lagi untuk makan masakan khas sunda, mereka lebih memilih untuk makan masakan modifikasi, makanan Fast Food, makanan western, dan lain-lain yang menjadi salah satu faktor kurangnya pengetahuan remaja akan masakan sunda.

Menurut Rouffaer (1905) dalam buku Dinas Kebudayaan dan Pariwisata (2011, hlm 70) Suku sunda adalah kelompok etnis yang berasal dari bagian barat pulau Jawa, Indonesia, dengan istilah Tatar Pasundan yang mencakup wilayah administrasi provinsi Jawa Barat, Banten, Jakarta, Lampung dan wilayah 
barat Jawa Tengah (Banyumasan). Orang Sunda tersebar diberbagai wilayah Indonesia, dengan provinsi Banten dan Jawa Barat sebagai wilayah utamanya.

Pengetahuan merupakan hasil "tahu" dan terjadi setelah orang melakukan penginderaan terhadap suatu objek tertentu. Penginderaan terjadi melalui panca indera manusia, yaitu indera pengelihatan, indera penciuman, indera pendengaran, indera perasa, dan indera peraba. Pengetahuan atau kognitif merupakan domain yang sangat penting dalam membentuk tindakan seseorang (Notoatmojo : 2010, hlm 26).

Bagi orang Sunda yang dimaksud dengan makanan adalah Kadaharan yaitu suatu benda yang dapat dimakan. Dalam budaya sunda terdapat angapan bahwa "seseorang belum dikatakan makan apabila belum makan nasi dengan lauk pauknya". Misalnya, biarpun sudah makan ubi atau singkong rebus satu piring, jagung rebus satu piring, dan makan roti tiga buah tetap saja dianggap belum makan, karena anggapan yang dimakannya bukan nasi. (Dinas Kebudayaan Jawa Barat : 2005, hlm 28).

Makanan Pokok merupakan makanan yang dibuat dengan menggunakan bahan dari kabohidrat sebagai sumber tenaga. Nasi adalah beras yang sudah dimasak dengan berbagai teknik memasak dan siap disantap. Nasi sebagai makanan pokok, ada pula jenis - jenis makanan lain sebgai pelengkapnya, yang dikenal dengan istilah lauk - pauk.

Pada umumnya jenis lauk pauk yang dikenal orang Sunda dibedakan dua jenis yaitu dari hewan dan dari tumbuhan. Bahan makanan yang berasal dari hewan antara lain daging, ikan dan telur. Lauk pauk selain daging dan ikan, masyarakat mengenal pula lauk pauk yang bersal dari nabati, misalnya tahu, tempe, oncom, tauco, dan kecap. (Dinas Kebudayaan Jawa Barat : 2005, hlm 30).

Sayur - sayuran merupakan makanan populer bagi masyrakat sunda karena mayoritas masyarakat bermata pencaharian sebagai petani. Sayur merupakan hidangan berkuah sebagai pelengkap dari makanan pokok baik nasi maupun pengantinya, berisikan sayuran.

Pelengkap hidangan dalam masakan Sunda mrupakan hal yang wajib karena dalam budaya Sunda, makan tanpa sambal rasanya kurang nikmat dan kurang sempurna. Sebagai pelengkap makan, orang Sunda mengenal lalab, lalapan, yaitu sayur mayur yang dimakan bersama sambel, sambal. . (Dinas Kebudayaan Jawa Barat : 2005, hlm 32)

Jurnal Ayu Nurwitasari (2015) tentang Pengaruh Wisata Gastronomi Masakan Tradisional Sunda Terhadap Keputusan Wisatawan Berkunjung ke Kota Bandung menyatakan hasil bahwa wisata gastronomi makanan tradisional di Kota Bandung mendapatkan penilaian baik oleh wisatawan, tempat yang menjadi checkpoint adalah sepanjang Jalan Riau dan jalan sekitar Gedung Sate, hal ini membuktikan bahwa wisata gastronomi (tata boga) telah menjadi simbol penting bagi kepariwisataan Kota Bandung sehingga patut diadakannya pelestarian guna mencegah kepunahan makanan tradisional terutama makanan tradisional khas masyarakat Kota Bandung.

Rumusan masalah penelitian ini yaitu sebagai berikut : Berapa besar pengenalan nama dan ciri - ciri 
masakan khas Sunda yang terdiri dari makanan pokok, lauk pauk, sayur, dan penyerta di Kecamatan Kiaracondong?

Tujuan dalam penelitian ini adalah untuk memperoleh data mengenai :

1. Pengenalan nama dan ciri makanan pokok khas sunda yang terdiri dari nasi tutug oncom, nasi liwet, nasi pepes, nasi timbel, dan nasi tumpeng.

2. Pengenalan nama dan ciri lauk pauk hewani khas sunda yang terdiri dari Ayam goreng lengkuas, Ayam serundeng, ayam bakar, pepes ayam, ikan goreng, ikan bakar, pepes ikan, Sate Maranggi, goreng jeroan, dan gepuk.

3. Pengenalan nama dan ciri hidangan lauk pauk nabati khas sunda yang terdiri dari pepes tahu dan oseng oncom.

4. Pengenalan nama dan ciri sayur khas sunda yang terdiri dari sayur kacang merah, sayur asem, sayur lodeh, Soto Bandung, ulukutek leunca, lotek mentah, lotek matang, karedok, dan urab.

5. Pengenalan nama dan ciri penyerta khas sunda yang terdiri dari lalapan, sambal terasi, sambal oncom, dan sambal tauco.

\section{METODE PENELITIAN}

Metode penelitian yang digunakan penulis adalah metode penelitian deskriptif dengan pendekatan kuantitatif sebagai metode yang berlandaskan pada filasafat positivism, digunakan untuk meneliti populasi atau sampel tertentu, teknik pengumpulan data menggunakan instrumen peneltitian, analisis yang bersifat kuantitatif/statistik dengan tujuan untuk menguji hipotesis yang telah ditetapkan (Sugiyono : 2016, hlm 14). Subjek penelitian adalah siswa SMP dan SMA negeri kelas 3 yang berada di Kecamatan Kiaracondong. Sampel yang digunakan dalam penelitian ini adalah Proporsionate Stratified Random Sampling dan didapatkan hasil sebanyak 99 responden. Metode pengumpulan data berupa tes dan angket skala Guttmen yang digunakan untuk mengukur pengenalan nama dan ciri - ciri masakan sunda. Sebelum digunakan dalam penelitian, tes penelitian terlebih dahulu diuji kelayakannya dengan melakukan validasi Jugdement Experts.

Sebanyak 30 soal diberikan pada 99 responden siswa kelas 3 yang berada di SMPN 30 Bandung, SMPN 37 Bandung, SMAN 12 Bandung, dan SMAN 16 Bandung. Hasil jawaban responden diinventaris kemudian dilakukan tabulasi data menggunakan bantuan Microsoft Excel 2013.

Instrumen yang telah diskor dipersentasekan dan dikategorikan mengadopsi pendapat yang dikemukan oleh Santoso (2001, hlm 37) mengenai presentase pengelompokan jawaban responden, yang disesuaikan dengan berapa banyak responden yang mengenal masakan khas sunda adalah:

$$
\begin{array}{ll}
100 \% & =\text { Seluruhnya } \\
75 \%-99 \% & =\text { Sebagian Besar } \\
51 \%-74 \% & =\text { Lebih dari setengahnya } \\
50 \% & =\text { Setengahnya } \\
25 \%-49 \% & =\text { Kurang dari setengahnya } \\
1 \%-24 \% & =\text { Sebagian kecil } \\
0 \% & =\text { Tidak seorangpun }
\end{array}
$$

\section{TEMUAN PENELITIAN.}

Data hasil penelitian mengenai pengenalan makanan pokok khas sunda menunjukan skor tertinggi angket yaitu Nasi Liwet dengan 100\% 
dan terendah yaitu Nasi Tutug Oncom dengan $67,7 \%$, dan hasil tes yaitu Nasi Tumpeng dengan $96 \%$ dan hasil terendah yaitu hidangan Nasi Pepes dengan $77 \%$. Hasil rata - rata angket sebesar $86,2 \%$ dan tes sebesar $86,6 \%$ menyatakan bahwa sebagian besar responden mengenal nama dan ciri ciri makanan pokok khas sunda

Data hasil penelitian mengenai pengenalan lauk pauk hewani khas sunda menunjukan hasil angket skor tertinggi terdapat pada Ayam Goreng, Ikan Goreng, dan Ikan Bakar dengan skor $100 \%$ yang artinya Seluruh responden mengenal nama ikan bakar, dan skor terendah terdapat pada Ayam Goreng Lengkuas dengan skor 57,6\% yang artinya Lebih dari Setengah responden mengenal nama Ayam goreng Lengkuas. Hasil tes menunjukan skor tertinggi terdapat pada hidangan Ayam Bakar dengan hasil $98 \%$ yang artinya sebagian besar responden mengenal ciri - ciri dari masakan tersebut, dan skor terendah terdapat pada hidangan Ayam Goreng Lengkuas dengan hasil $63,6 \%$ yang artinya lebih dari setengah responden mengenal ciri - ciri dari hidangan tersebut. Hasil rata - rata angket sebesar $86,34 \%$ dan tes sebesar $84,43 \%$ menyatakan bahwa sebagian besar responden mengenal ciri - ciri hidangan lauk pauk hewani khas sunda.

Data hasil penelitian mengenai pengenalan lauk pauk nabati khas sunda pada hasil angket sebesar 91,9\% menunjukan bahwa nama oseng oncom lebih banyak dikenal dibandingkan dengan nama pepes tahu yang hanya sebesar $57,6 \%$, namun pada tes menunjukan hasil sebesar $100 \%$ atau seluruh responden mengenal ciri - ciri dari hidangan pepes tahu dan sebanyak $55 \%$ atau lebih dari setengah responden mengenal ciri - ciri dari hidangan Oseng Oncom. Hasil rata - rata angket sebesar $74,7 \%$ dan tes sebesar $77,5 \%$ menyatakan bahwa sebagian besar responden mengenal ciri - ciri lauk pauk nabati khas sunda.

Data hasil penelitian mengenai pengenalan sayur khas sunda pada hasil angket menunjukan bahwa skor terendah terdapat pada Ulukutek Leunca dengan skor $54,5 \%$ dan hasil tertinggi terdapat pada Sayur Asem dengan skor 98\%. Hasil tes menunjukan skor tertinggi terdapat pada hidangan Ulukutek Leunca dengan skor $96 \%$ yang artinya sebagian besar resonden mengetahui ciri - ciri hidangan tersebut, dan skor terendah terdapat pada hidangan Karedok dengan skor $45,5 \%$ yang artinya kurang dari setengah jumlah responden mengetahui ciri - ciri hidangan tersebut. Hasil rata - rata angket sebesar $82,6 \%$ dan tes sebesar $81,92 \%$ menyatakan bahwa sebagian besar responden mengenal ciri - ciri hidangan sayuran khas sunda.

Data hasil penelitian mengenai pengenalan penyerta khas sunda pada hasil angket menunjukan bahwa skor tertingi terdapat pada hidangan Sambal Terasi dengan 99\% dan skor terendah terdapat pada Sambal Tauco dengan skor 57,6\%. Hasil tes menunjukan skor tertinggi terdapat pada hidangan Sambal Terasi dengan skor $88 \%$, dan skor terendah terdapat pada hidangan Sambal Tauco dengan skor $70,7 \%$. Hasil rata - rata angket sebesar 78,8\% dan tes sebesar $80,9 \%$ menyatakan bahwa sebagian besar responden mengenal ciri - ciri penyerta masakan khas sunda. 


\section{PEMBAHASAN}

Pengenalan nama dan ciri - ciri masakan khas sunda yang menjadi bagian dari penelitian meliputi makanan pokok, lauk pauk hewani, lauk pauk nabati, sayur, dan penyerta khas sunda. Pembahasan untuk hasil angket dan tes yang dilakukan didasarkan pada teori Notoatmojo (2010, hlm 26) yang menyebutkan bahwa pengetahuan merupakan hasil "tahu" dan terjadi setelah orang melakukan penginderaan terhadap suatu objek tertentu. Penginderaan terjadi melalui panca indera manusia, yaitu indera pengelihatan, indera penciuman, indera pendengaran, indera perasa, dan indera peraba.

Dilihat dari segi pengenalan nama dan ciri makanan pokok khas sunda penulis melihat perbedaan yang mencolok antara hasil angket dan tes pada hidangan Nasi Tutug Oncom. Hasil tes menunjukan hasil sebsar 94\% atau masuk dalam kategori Sebagian Besar, namun asil angket menunjukan hasil sebesar $67,7 \%$ atau termasuk dalam kategori Lebih dari Setengahnya. Artinya, responden memiliki pengetahuan yang lebih mendalam mengenai nasi tutug oncom apabila telah melihat gambar dan ciri dari hidangan tersebut, kemudian dikuatkan oleh teori yang disampaikan oleh Dinas Kebudayaan Jawa Barat (2004, hlm 25) bahwa sebagai makanan pokok, nasi memiliki arti yang sangat penting dalam pandangan hidup orang Sunda yang tampak jika dalam suatu keluarga telah memiliki persediaan beras cukup, mereka merasa aman, reugreug.

Pada bagian lauk pauk hewani perbedaan yang mencolok antara hasil angket dan tes pada hidangan Ayam Serundeng dan Sate Maranggi. Hasil angket Ayam Serundeng menunjukan hasil sebesar $98 \%$ atau berada dalam kategori Sebagian Besar, namun hasil angket menunjukan hasil sebesar $73 \%$ atau berada pada kategori Lebih dari Setengahnya. Berbeda dengan hidangan Sate Maranggi, hasil tes sebesar $88,9 \%$ atau termasuk dalam kategori Sebagian Besar, namun hasil angket Sate Maranggi hanya sebesar $59,6 \%$ atau termasuk dalam kategori Lebih dari Setengahnya. Lauk pauk hewani merupakan hidangan yang umum di kalangan masyarakat sunda sesuai dengan teori yang dikemukakan Dinas Kebudayaan Jawa Barat (2005, hlm 26) bahwa untuk memenuhi konsumsi rumah tangga, masyarakat pada umumnya memlihara ayam kampung bukan ayam ras, petelur atau pedaging, kemudian lauk pauk tidak hanya dari daging tapi juga dari ikan. Ikan yang biasa dimakan terdiri dari 2 jenis yaitu ikan air tawar. Ikan air tawar adalah ikan yang dipelihara di kolam-kolam, sawah, maupun danau.

Pengenalan nama dan ciri lauk pauk nabati khas sunda penulis melihat adanya perbedaan hasil antara hasil angket dan hasil tes. Hidangan pepes tahu pada tes menunjukan hasil $100 \%$ atau masuk dalam kategori seluruhnya dan hasil angket menunjukan angka 55\% atau masuk dalam kategori lebih dari setengahnya. Hasil angket hidangan oseng oncom sebesar $91,9 \%$ atau masuk dalam kategori sebagian besar dan pada tes menunjukan hasil $57,5 \%$ atau masuk dalam kategori lebih dari setengahnya. Dikuatkan oleh teori yang dikemukakan oleh Dinas Kebudayaan Jawa Barat (2005, hlm 26) bahwa lauk pauk selain daging dan ikan, masyarakat mengenal pula lauk pauk yang bersal dari nabati, misalnya tahu, tempe, oncom, tauco, dan kecap. Bahkan, daerah penghasil makanan - 
makanan khas tersebut sampai populer di seluruh Jawa Barat, seperti oncom dari Bandung, tahu dari Sumedang, kecap dari Ciamis, dan Majalengka, serta tauco dari Cianjur.

Pada pengenalan nama dan ciri pada hidangan sayur khas sunda penulis melihat perbedaan yang mencolok antara hasil angket dan hasil tes pada hidangan Ulukutek Leunca dan Karedok. Hasil tes ulukutek leunca yang jauh lebih besar yaitu sebesar $96 \%$ atau berada pada kategori Sebagian Besar, dibandingkan dengan hasil angket Ulukutek Leunca jauh lebih kecil yaitu sebesar $54,5 \%$ atau berada pada kategori Lebih dari Setengahnya. Berbeda dengan hidangan Karedok yang hasil angketnya jauh lebih besar yaitu $88,9 \%$ atau termasuk dalam kategori Sebagian Besar, namun hasil tesnya sangat kecil yaitu hanya sebesar $45,5 \%$ atau termasuk dalam kategori Kurang dari Setengahnya. Berdasarkan teori pada bab 2 menurut Murdijati (2017, hlm 97-100) "bahwa sayur - sayuran merupakan makanan populer bagi masyrakat sunda karena mayoritas masyarakat bermata pencaharian sebagai petani, meskipun hidangan tersebut mengandung bahan protein, namun masyarakat Sunda tetap menyebutnya dengan sayur.

Pada hidangan penyerta khas sunda perbedaan hasil yang mencolok terdapat pada hidangan Sambal Tauco. Hasil tesnya lebih tinggi yaitu sebesar $70,7 \%$ atau termasuk dalam kategori Sebagian Besar, namun hasil angket Sambal Tauco lebih kecil yaitu sebesar $57,6 \%$ atau termasuk dalam kategori Lebih dari Setengahnya. Terdapat teori pada bab 2 yang dikemukakan oleh Dinas Kebudayaan Jawa Barat (2005, hlm 38) bahwa "sebagai pelengkap makan, orang
Sunda mengenal lalab, lalapan, yaitu sayur mayur yang dimakan bersama sambel, sambal. Masyarakat sunda merasa bahwa makan tanpa sambal rasanya kurang nikmat, maka wajar apabila di setiap rumah atau bahkan rumah makan pun selalu disediakan sambal sebagai penyerta hidangan khas sunda" dan teori yang dikemukakan oleh Pranata (2007, hlm 30) bahwa "tauco merupakan hasil fermentasi kedelai putih yang berfungsi menambah aroma. Rasanya tajam, sangat asin, berbau khas, dan warnanya kecoklatan. Tauco jika ditelusuri berasal dari dunia kuliner Cina, namun di Indonesia pabrik tauco yang terkenal berada di Cianjur".

Setelah membandingkan hasil antara angket dan tes penulis melihat bahwa sebagian besar responden memiliki pengetahuan tentang nama dan ciri - ciri hidangan khas sunda yang meliputi makanan pokok, lauk pauk hewani, lauk pauk nabati, sayuran, dan hidangan penyerta, meskipun ada hidangan yang memiliki perbedaan yang jauh antara hasil angket dan hasil tes diantaranya Nasi Tutug Oncom, Ayam Serundeng, Sate Maranggi, Pepes Tahu, Oseng Oncom, dan Sambal Tauco. Sesuai dengan teori yang dikemukakan oleh Dinas Kebudayaan dan Pariwisata (2011, hlm 76) bahwa "sebanyak $74 \%$ penduduk yang mendiami wilayah Jawa Barat adalah suku Sunda", maka banyak responden yang mengenal nama dan ciri dari hidangan khas sunda.

Berdasarkan hasil angket dan tes secara keseluruhan, penulis melihat bahwa hasil angket dan tes tidak memiliki keterkaitan satu sama lain, bisa saja hasil angket lebih besar namun hasil tes lebih kecil, ataupun sebaliknya. Responden juga tidak 
dapat dipaksakan untuk mengenali hidangan berdasarkan nama ataupun ciri - ciri hidangan tersebut, dalam hal ini pengetahuan responden mengenai masakan khas sunda dapat terlihat hanya sebatas mengenal nama saja, hanya dapat mengenali hidangan apabila ditunjukan ciri - ciri hidangan tersebut, atau keduanya (dapat mengenali nama dan mengenali ciri ciri hidangan tersebut).

\section{SIMPULAN DAN \\ REKOMENDASI \\ Simpulan}

Simpulan dari penelitian "Pengenalan Tentang Masakan Sunda di Kalangan Remaja Kecamatan Kiaracondong" diantaranya adalah:

1. Hasil dari presentase instrumen mengenai makanan pokok khas sunda menunjukan bahwa responden Sebagian Besar mengenal nama dan ciri - ciri makanan pokok khas sunda dengan hasil perbedaan angket dan tes paling terlihat terdapat pada hidangan Nasi Tutug Oncom.

2. Hasil dari presentase instrumen mengenai lauk pauk hewani khas sunda menunjukan bahwa responden Sebagian Besar mengenal nama dan ciri - ciri lauk pauk hewani khas sunda dengan hasil perbedaan angket dan tes paling terlihat terdapat pada Ayam Serundeng dan Sate Maranggi.

3. Hasil dari presentase instrumen mengenai lauk pauk nabati khas sunda menunjukan bahwa responden Sebagian Besar mengenal nama dan ciri - ciri lauk pauk nabati khas sunda dengan hasil angket tertinggi mengenai pengenalan nama lauk pauk nabati khas sunda terdapat pada hidangan Oseng Oncom dan hasil tes tertinggi mengenai pengenalan ciri lauk pauk nabati khas sunda terdapat pada hidangan Pepes Tahu.

4. Hasil dari presentase instrumen mengenai sayuran khas sunda menunjukan bahwa responden Sebagian Besar mengenal nama dan ciri - ciri sayuran khas sunda dengan hasil perbedaan angket dan tes paling terlihat terdapat pada hidangan Ulukutek Leunca dan Karedok.

5. Hasil dari presentase instrumen mengenai penyerta khas sunda menunjukan bahwa responden Sebagian Besar mengenal nama dan ciri - ciri penyerta khas sunda dengan perbedaan hasil angket dan tes paling terlihat terdapat pada hidangan Sambal Tauco.

\section{Rekomendasi}

Hasil penelitian menunjukan bahwa pengenalan nama dan ciri - ciri masakan khas sunda di kalangan remaja Kecamatan Kiaracondong berada pada kriteria sebagian besar mengenal nama dan ciri - ciri walaupun terdapat perbedaan yang sangat terlihat pada beberapa hidangan, sehingga penulis mengajukan rekomendasi yang dapat dipertimbangkan sebagai bahan masukan bagi beberapa pihak.

Penulis memberikan rekomendasi untuk orang tua serta tenaga pendidik yang terkait untuk mengenalkan hidangan khas daerah, khususnya hidangan khas sunda terutama pada hidangan yang terlihat perbedaan antara hasil angket dan hasil tes seperti hidangan Nasi Tutug Oncom, Ayam Serundeng, Sate 
Maranggi, Oseng Oncom, Pepes Tahu, Ulukutek Leunca, Karedok, dan Sambal Tauco agar generasi selanjutnya dapat mewariskan hidangan tersebut sehingga tidak punah. Pengenalan dapat dilakukan sejak dini dengan mengenalkan nama, ciri - ciri, bentuk, tekstur, dan rasa hidangan tersebut. Anak juga diajarkan untuk membandingkan antara hidangan satu dengan hidangan lain, sehingga pengetahuan anak mengenai masakan khas sunda tidak punah dan dapat dilanjutkan pada generasi selanjutnya. Penelitian ini juga dapat menjadi rujukan bagi penelitian selanjutnya yang berkaitan tentang masakan daerah khususnya masakan sunda.

\section{DAFTAR PUSTAKA}

Badan Pusat Statisktik. (2016). Jumlah Populasi Kota Bandung dan Peningkatannya Tahun 2016. Bandung : BPS.

Dharmaputra, T.S. (2015). Kumpulan Masakan Favorit Sepanjang Masa. Jakarta : Kriya Pustaka

Direktorat Universitas Pendidikan Indonesia. (2016). Pedoman Penulisan Karya Ilmiah. Bandung: UPI

Hadi, Protasius Hardono. (1994). Epistemologi, Pengetahuan. Yogyakarta : Konisius.
Kemendikbudpar. (2005). Makanan dalam Khazanah Budaya. Bandung : Kemdikbud

Kemendikbudpar. (2011). Ensiklopedia Jawa Barat 2. Jakarta : Lentera Abadi

Murdijati, dkk. (2012) Resep Rahasia Turun Temurun Sumatera, Jawa, dan Sulawesi. Yogyakarta : Great! Publisher.

Murdijati, dkk. (2017). Profil Struktur, Bumbu, dan Bahan Dalam Kuliner Indonesia. Yogyakarta: Gadjah Mada University Press

Nurwitasari, Ayu. (2015). Pengaruh Wisata Gastronomi Masakan Tradisional Sunda Terhadap Keputusan Wisatawan Berkunjung ke Kota Bandung Jurnal Sekolah Tinggi Pariwisata Bandung. II. 97-102. doi: $\quad$ http://ejournal.stpbandung.ac.id/index.php/v01/arti cle/view/34

Pranata, Martha \& Nanit. (2008). 505 Masakan Nusantara Favorit. Yogyakarta : Gradien Mediatama

Rahmawaty, Utami. (2015). Pelestarian Budaya Indonesia Melalui Pembangunan Fasilitas Pusat Jajanan Tradisional Jawa Barat. Jurnal Tingkat Sarjana Bidang Senirupa dan Desain. I. 1-5. doi: jurnals1.fsrd.itb.ac.id/index.php/interior/ article/viewFile/236/210 